\title{
Adoption of Hybrid Rice in Bangladesh: Farm Level Experience
}

\author{
M. M. I. Shah ${ }^{1}$, Will J. Grant ${ }^{1} \&$ Sue Stocklmayer ${ }^{1}$ \\ ${ }^{1}$ Australian National Centre for the Public Awareness of Science, The Australian National University, Canberra, \\ ACT, Australia \\ Correspondence: M. M. I. Shah, Australian National Centre for Public Awareness of Science, The Australian \\ National University, Physics Link Building 38, Science Road, ACT 0200, Australia. Tel: 61-2-6125-7634. E-mail: \\ md.shah@anu.edu.au
}

\author{
Received: April 16, 2014 Accepted: May 9, 2014 Online Published: June 15, 2014 \\ doi:10.5539/jas.v6n7p157 URL: http://dx.doi.org/10.5539/jas.v6n7p157
}

\begin{abstract}
The purpose of the study was to understand the farmers' response to hybrid rice over the last decade. To achieve this, we used the "diffusion of innovation" model as developed by Rogers. The specific objectives guiding the study were to: i) describe the socio-economic and demographic characteristics of the farmers; ii) survey the varieties of hybrid rice cultivated over the last decade and identify the best performers; iii) assess the extent of adoption of hybrid rice in Bangladesh; iii) investigate the influence of selected characteristics in influencing farmers' decisions on adopting hybrid rice. The study was conducted in five regions of Bangladesh. A concurrent embedded design using a cross sectional survey was employed. The population of this study consisted of rice growers of the boro season who were responsible for farming decisions. A multistage stratified random sampling design was employed in selecting the sample of 425 farmers. Data were collected through face-to-face interviews using a pre-tested and back translated questionnaire. Data confirmed that the overall extent of adoption of hybrid during the period of 2001-2011 boro seasons was relatively low in the sample areas. Logistic regression results after fitting the full model of eleven selected predictive variables on farmers' decisions in adopting hybrid rice showed that education, annual family income, communication exposure, and attitude towards hybrid rice made significant contributions to farmers' decisions in adopting hybrid rice. There is an enormous potential for improving the level of adoption of hybrid rice in Bangladesh.
\end{abstract}

Keywords: non-adopter, de-adopter, continuing adopter, adoption, hybrid rice, Bangladesh

\section{Introduction}

Bangladesh is primarily an agrarian economy with a high population density where food security remains a major concern. Agriculture plays an important role in the creation of rural employment and generation of income in Bangladesh and is therefore considered a lifeline of the Bangladesh economy. The contribution of agriculture sector to the Gross Domestic Product (GDP) is 22\% (BER, 2008 as cited in Ahmed Khan, Ziaul Karim, Jeong, Kim, \& Rahman, 2013). Rice is the most important food crop in Bangladesh, in terms of consumption, production, and area coverage. In the agricultural sector, the crop sub-sector dominates with $14.3 \%$ in GDP of which rice itself contributes about $53 \%$. Rice contributes more than $80 \%$ to the total food supply. More than $95 \%$ of population consumes rice and it alone provides $76 \%$ of calorie and $66 \%$ of total protein requirements of the daily food intake (Salam et al., 2009; Bhuiyan et al., 2002). As rice is essential for producers and consumers alike, the Government of Bangladesh is working to promote rice research and development. It is especially focused on improving rice yields that will allow the country to remain self-sufficient despite the nation's population growth rate of $1.5 \%$ per annum (Julfiquar, 2002) by making this sector commercially profitable, technically feasible and environmentally sound (Ahmed Khan et al., 2013).

Even though Bangladesh has achieved significant progress in agriculture, especially with respect to rice production and yields, the demand for rice still outstrips domestic production, and the country remains a net importer of rice (FPMU 2008 as cited in Ganesh-Kumar, Prasad, \& Pullabhotla, 2012). Recent projections indicate that the annual increase in per capita rice demand is in the range of 0.85 to $1.2 \mathrm{~kg}$ (Ganesh-Kumar et al., 2012). Alongside population growth at the rate of 1.32 percent per annum (BER, 2010, as cited in Awal \& Siddique, 2011), declines in rice yield growth rates and land pressures from urbanization have left Bangladesh searching for ways of improving rice yields. Among the various options available, hybrid rice technology is the most feasible and readily adoptable, following ample demonstration in China (Nirmala \& Suhasini, 2013; 
Nirmala, Vasudev, \& Suhasini, 2013) and a wide range of studies noting the benefits of the technology including yield increases over conventional open pollinated varieties (OPV), increases in farm incomes, and stabilized grain prices for both urban and rural consumers (Spielman, Kolady, Ward, Rashid, \& Gulati, 2012). It is also asserted that hybrid rice could play an important role in food security, especially in poor countries in the tropics, where populations are soaring and agricultural areas shrinking (Santiaguel \& Quipot, 2012). The 'father of hybrid rice', Professor Longping Yuan, has argued that Bangladesh can be self sufficient through the cultivation of hybrid rice (2012). Despite these potential benefits, hybrid rice adoption remains relatively low in Bangladesh. As of 2009-10, only 6 percent of total agricultural area was used to cultivate hybrid rice (Rashid, Julfiquar, \& Ali, 2011).

In order to feed the growing population, hybrid rice research and development began in the 1993 at the Bangladesh Rice Research Institute (BRRI), although concerted efforts were not undertaken until 1996 with additional technical support from the International Rice Research Institute (IRRI) and financial support from Bangladesh Agricultural Research Council (BARC) (Julfiquar, 2002; Rashid et al., 2011). It did not receive high priority on the public research agenda until after 2000. In 2001, the government of Bangladesh released their first governmentally developed national hybrid, a variety called BRRI hybrid dhan-1 (Julfiquar, 2002). In 1998-99 widespread floods led to shortfalls in domestic seed supply, leading the National Seed Board (NSB) to allow imports of two hybrid varieties: Aalok, a variety from China, and Sonar Bangla, a variety from India. It was the private sector that took a lead in the introduction of hybrid rice in Bangladesh without a clear deployment strategy (Hossain, Janaiah, \& Husain, 2003).

Getting a new idea adopted, even when it has obvious advantages, is difficult (Rogers, 2003). It is a common experience that the adoption of an apparently useful agricultural technology is slower than predicted, or desired, by extension agents (Röling, 1988). Masangano and Miles (2004) pointed out "when an agricultural program introduces a new agricultural technology, the program must be able to evaluate whether the technology has been adopted. Of equal importance is the need to identify the factors that influence adoption". Hybrid rice is no exception. The success of any technology depends on its dissemination among the potential users, which ultimately is measured by the level of adoption of the technology. Although some research on the adoption of hybrid rice has been conducted in Bangladesh, no study has dealt with post adoption actors, i.e. continuing adopters or de-adopters (those who discontinue after having previously adopted).

After the release of hybrid varieties in the year of 1999, due to the lack of information flow and experience with the new varieties, adoption was limited and slow. In order to prepare programs and courses of action for wider adoption of hybrid rice, it is important to know the current status of hybrid rice in Bangladesh in terms of area they brought under cultivation. The following specific objectives were set to guide the study: i) to describe the socio-economic and demographic characteristics of the farmers; ii) to survey the varieties of hybrid rice cultivated over the last decade and identify the best performers; iii) to assess the extent of adoption of hybrid rice in Bangladesh, iv) to investigate the influence of selected characteristics in influencing farmers' decisions on adopting hybrid rice.

\section{Research Methods}

\subsection{Research Site}

The land use pattern of Bangladesh is influenced by agro ecology, soil physiographic and climatic factors (BBS, 2011). Considering the variations of all these factors the total land area of Bangladesh has been classified into nine regions of which at least five have been approved through the gazette notification of the Government of Bangladesh for evaluation and registration of every single variety of hybrid rice (GoB, 2003). Therefore five regions were taken into account for this study in order to select the sample (Figure 1).

\subsection{Sampling Design}

A concurrent embedded design using a cross sectional survey was employed (Creswell, 2009). The population of this study consisted of rice growers of the boro season as hybrids in Bangladesh are primarily cultivated during the boro season: generally transplanted in December-January and harvested in May-June (McFall, Magnan, \& Spielman, 2013). A multistage stratified random sampling design as proposed by Babbie (1990) was employed in selecting the sample. In order to maintain the level of precision (sampling error) at $( \pm 5)$ percent, the level of confidence at $95 \%$ and the degree of variability at 50 percent, 425 farmers were selected following sample size recommendations as proposed by Israel (2009), Dillman (2007) and Corbetta (2003). Farmers in three categories were sampled: namely, non-adopters (79), de-adopters (122) and continuing adopters (224) of hybrid rice. 
Data were collected through face-to-face interviews with the sampled farmers using a pre-tested and back translated questionnaire. Through prior consultation, we designed an 8-page questionnaire comprising 183 items in a series of 21 questions sequencing from general to specific. The questionnaire was formatted with both open and closed question items to obtain both quantitative and qualitative data. For data collection the primary investigator spent 120 working days travelling to different places of the selected research sites between March 2 and June 30, 2012.

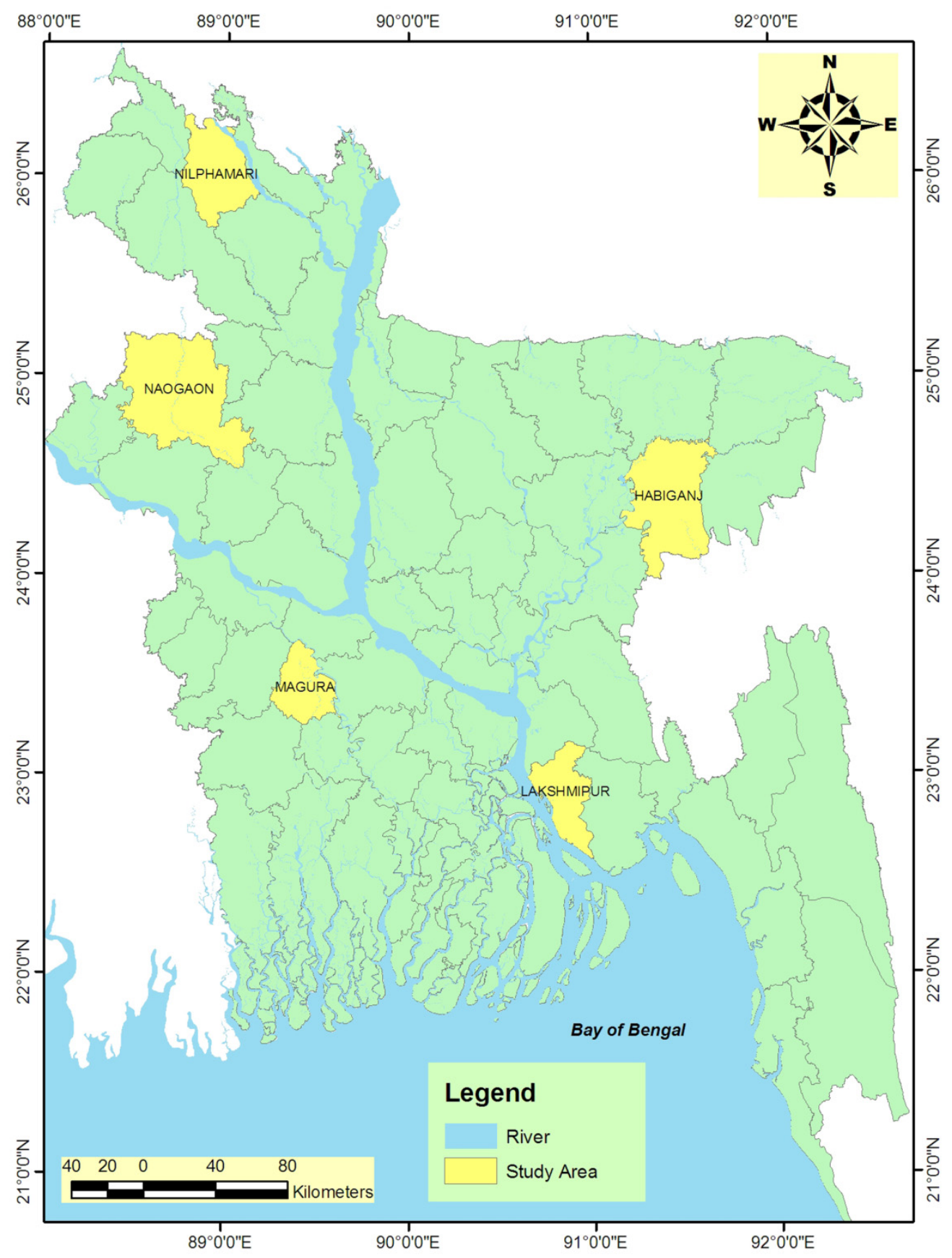

Figure 1. Map of Bangladesh showing selected districts under study

\subsection{Measuring Potential Area for Hybrid Rice Cultivation}

The potential area for hybrid rice cultivation was computed in order to measure the extent of adoption, which is referred to the total land area suitable for cultivation of rice by a respondent to the interview irrespective of its 
nature of occupancy. This criterion set as the focus of research was on the area coverage of hybrid rice, ignoring the tenurial arrangement. Using these criteria, the total potential area for hybrid rice cultivation was calculated using the following formula:

$$
\mathrm{FS}_{1}=\mathrm{A}_{1}+\mathrm{A}_{2}+\mathrm{A}_{3}-\mathrm{A}_{4}+\mathrm{A}_{5}
$$

Where,

$\mathrm{FS}_{1}=$ total land area suitable for hybrid rice cultivation irrespective of its sources of occupancy;

$\mathrm{A}_{1}=$ Land the respondent owned;

$\mathrm{A}_{2}=$ Land shared in;

$\mathrm{A}_{3}=$ Land shared out;

$\mathrm{A}_{4}=$ Land mortgaged out;

$\mathrm{A}_{5}=$ Land mortgaged in.

\subsection{Measuring Extent of Adoption}

The rate of adoption is defined as the speed with which an innovation is adopted by the individuals of a system. It can be measured in many ways: as the percentage of individuals who have adopted an innovation at a determined time; as the time necessary for a given percentage of individuals to adopt it; as the yearly average percentage of adoption; as the time for complete adoption, etc (Parra-Lopez, De-Haro-Gimenez, \& Calatrava-Requena, 2007). In particular adoption rates are expressed by Hubbard and Sandmann (2007) as a simple percentage: for example "34\% of participants adopted practice ' $\mathrm{X}$ ' based on a follow-up survey conducted 'Y' months after the program". In some other empirical studies adoption rates were calculated across the stages of adoption process in terms of percentages of the individuals who had adopted the concerned technology (Miller et al., 2008; Mackrell et al., 2009; Agwu et al., 2008). A precise quantitative definition is put forwarded by Feder, Just, and Zilberman (1985) as "Adoption of a single technology without considering other technologies can be measured by the proportion of the cropped area applied with that technology", which has been applied in the study of Parra-Lopez et al. (2007); Marasas, Anandajayasekeram, Millard, and Rooyen, (2006). Likewise, in this study the extent of adoption was measured at the individual farm level in a cultivating year as the percentage of the total potential area belonging to an individual farmer that was brought under cultivation of hybrid rice. If farmers continue cultivating hybrid rice for successive years, the average of both actual area and potential area were calculated to find the extent adoption of a given time period.

$$
\text { Extent of adoption of hybrid rice }(\%)=\frac{\text { Average of acreage planted to hybrid rice }}{\text { Average of total of potential acreage for hybrid rice }} \times 100
$$

In order to compute the above equation, farmers were asked first whether they had planted hybrid rice during the tenure of the 2001 boro season to 2011 boro season. If they had not, the researcher asked them the underlying causes for non-adoption. If they had, questions were asked about the total amount of potential acreage for hybrid rice cultivation they have and the acreage they have planted each year. With this information the researcher was also able to determine, for each year, the proportion of farmers who cultivated hybrid rice, as well as the proportion who were "newcomers," that is, began cultivating hybrid rice for the first time in a particular year, and those who would be "continuing adopters" as well. For those who discontinued hybrid rice cultivation, additional questions were asked about the reasons that lead them to discontinue. This methodological approach has been adopted from the work of Sofranko et al. (2004).

\subsection{Statistical Analysis}

We reviewed each survey for missing information (name of block, upazila and district), ineligible writing, and incomplete sentences and responses. Based on the outputs of the survey, various statistical data analyses including analyses of frequencies, percentage, range of scores, means, and standard deviations of the variables were performed. In order to test the difference of mean score between de-adopters and continued adopters with regard to their extent of adoption, an unpaired t test was conducted. To compare the groups of non-adopters, de-adopters and continuing adopters, Analysis of Variance (ANOVA) was performed. Logistic regression analysis was performed to assess the significant contribution of the independent variables on the adoption of hybrid rice. Five percent (005) level of probability with an accompanying 95 percent confidence level was used as a basis for rejecting the null hypotheses. 


\section{Results and Discussion}

\subsection{Socio-Economic and Demographic Profiles}

Studies have shown that farmers' personal characteristics have some influence on their perception of innovations and their decision to adopt or reject such innovations (Jegede, Bolorunduro, \& Ikani, 2007). In this study, such variations could influence the shape of perceptions and attitudes towards cultivating hybrid rice. Output analysis of variance (ANOVA) of explanatory variables is presented in Table 1. In addition, a graphical presentation of the selected characteristics of non-adopters, de-adopters and continuing adopters is shown in Figure 2.

Table 1. Descriptive statistics of explanatory variables by non-adopters, de-adopters and continuing adopters

\begin{tabular}{|c|c|c|c|c|c|c|}
\hline \multirow{3}{*}{$\begin{array}{l}\text { Variables } \\
\text { Age (years) }\end{array}$} & \multirow{2}{*}{\multicolumn{3}{|c|}{$\begin{array}{c}\text { Non-adopters De-adopters } \begin{array}{c}\text { Continuing } \\
\text { adopters }\end{array} \\
\text { Mean }\end{array}$}} & \multicolumn{2}{|c|}{$\begin{array}{c}\text { Total } \\
\text { respondents }\end{array}$} & \multirow{3}{*}{$\begin{array}{c}\mathrm{F} \\
\text { statistic } \\
1.335^{\mathrm{NS}}\end{array}$} \\
\hline & & & & \multirow{2}{*}{$\begin{array}{l}\text { Mean } \\
45.4\end{array}$} & \multirow{2}{*}{$\begin{array}{l}\text { SD } \\
12.1\end{array}$} & \\
\hline & 46.2 & 46.6 & 44.5 & & & \\
\hline Educational qualification (years) & 7.13 & 6.62 & 7.64 & 7.25 & 4.44 & $2.116^{\mathrm{NS}}$ \\
\hline Family size (persons) & 5.72 & 5.76 & 6.56 & 6.17 & 2.30 & $4.128^{*}$ \\
\hline Farm size (ha) & 1.02 & 1.17 & 1.92 & 1.54 & 1.99 & $10.46^{* * *}$ \\
\hline Annual family income ('000 USD) & 3.15 & 4.01 & 5.26 & 4.51 & 3.35 & $14.20 * * *$ \\
\hline Training experience (days) & 3.71 & 3.01 & 4.58 & 3.97 & 10.31 & $0.954^{\mathrm{NS}}$ \\
\hline $\begin{array}{l}\text { Membership in social organization } \\
\text { (composite scale score) }\end{array}$ & 23.25 & 33.18 & 42.85 & 36.43 & 74.43 & $2.199^{\mathrm{NS}}$ \\
\hline $\begin{array}{l}\text { Communication exposure } \\
\text { (composite scale score) }\end{array}$ & 26.51 & 28.54 & 33.42 & 30.74 & 9.42 & $21.66^{* * *}$ \\
\hline $\begin{array}{l}\text { Assessment of current promotional } \\
\text { activities (composite scale score) }\end{array}$ & 25.48 & 25.87 & 26.66 & 26.21 & 2.17 & $10.63 * * *$ \\
\hline Risk perception (composite scale score) & 21.37 & 22.0 & 20.21 & 20.94 & 3.37 & $12.33 * * *$ \\
\hline $\begin{array}{l}\text { Attitude towards hybrid rice (composite } \\
\text { scale score) }\end{array}$ & 44.91 & 45.45 & 50.58 & 48.05 & 7.14 & $33.85^{* * *}$ \\
\hline
\end{tabular}

Note: ${ }^{\text {NS }}$ indicates non significant; * indicates significant1 at $5 \%$ level $(0.01<\mathrm{p}<0.05)$; ** indicates significant1 at $1 \%$ level $(0.001<\mathrm{p}<0.01)$; $* * *$ indicates significant 1 at $0.1 \%$ level $(\mathrm{p}<0.001)$.

Table 1 reveals that no significant difference was found between non-adopters, de-adopters and continuing adopters as to age, educational qualification, training experience and membership in social organizations. A significant difference was found, however, between non-adopters, de-adopters and continuing adopters in terms of family size. Based on strong evidence, a significant difference was also found between de-adopters and continuing adopters in terms of farm size, annual family income, communication exposure, assessment of promotional activities, perception of risk, and attitude towards hybrid rice.

Table 1 and Figure 2 clearly demonstrated that as compared to non-adopters and de-adopters, continuing adopters possessed bigger farms (by 0.9 and 0.75 ha); earned higher annual incomes (by 2.1 and 1.25 in 000' USD); maintained better communication with information sources and channels (by scores of 6.91 and 4.88); made better assessment of promotional activities carried out by the organization concerned (by scores of 1.18 and 0.79 ); and formed more favorable attitudes towards cultivating hybrid rice (by a score of 5.67 and 5.13). De-adopters perceived a higher risk of cultivating hybrid rice compared with non-adopters and continuing adopters (by scores of 1.16 and 1.79). 


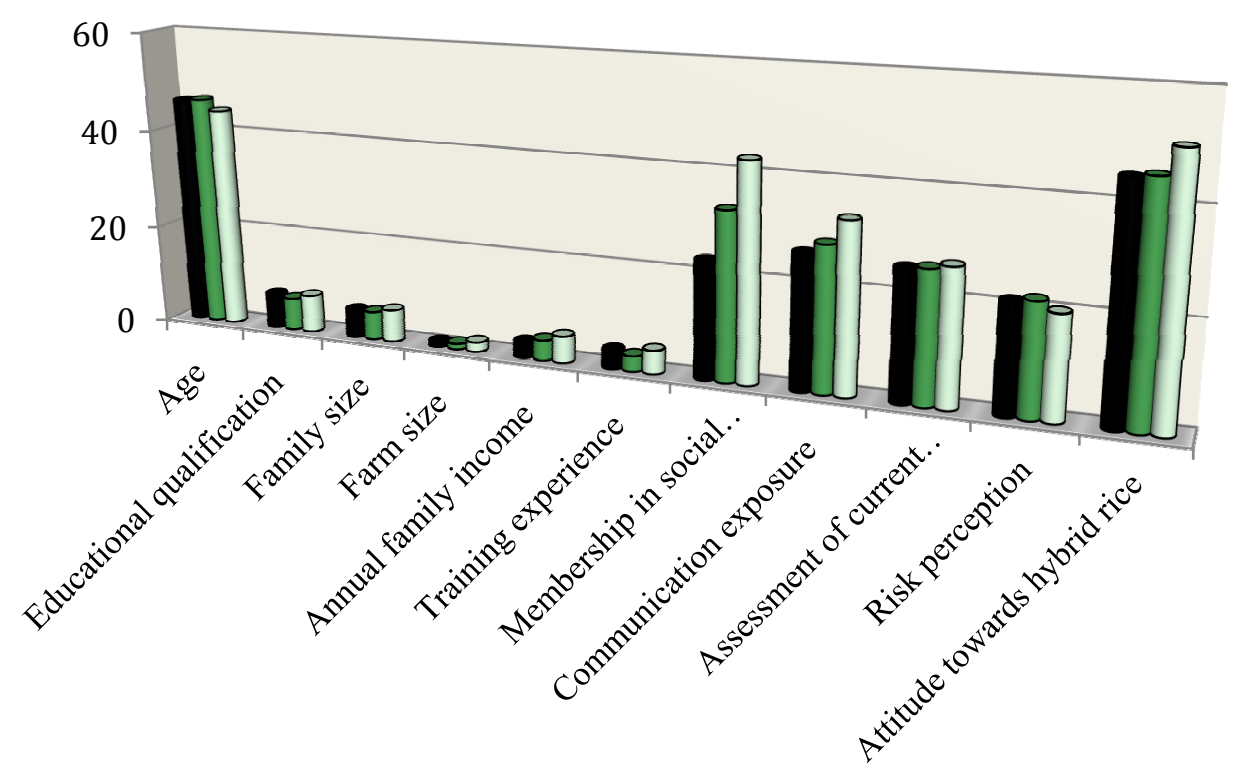

Figure 2. A graphical presentation of the selected characteristics of non-adopters, de-adopters and continuing adopters

\subsection{Varietal Information of Hybrid Rice Cultivated Over a Decade}

From 1998 to 2011, a total of 99 hybrid varieties were released in Bangladesh by the National Seed Board, Bangladesh (Hossain, 2011). Of all these varieties, 94 were released by Private firms or non-governmental organizations while only five came from public sectors organizations; four from Bangladesh Rice Research Institute (BRRI) and one from Bangladesh Agricultural Development Corporation (BADC).

At the field level, out of 99 varieties only 40 have been cultivated to a varying extent (Table 2). Such a wide range of varieties gave farmers an opportunity to go through a process of trial and error to secure best performance. Data presented in Table 2 clearly demonstrate that some varieties were found to be grown each season on a regular basis. These were ACI-1, ACI-2, Alloron, Arize Dhani, Heera-5, Heera-1, Heera-2 (HS-273), LP 70, Jagoron, Moyna (HTM-303), Tia (HTM-707), RICER-101, Sampad (93024), SL 8H Hybrid dhan, Sonar Bangla and Arize Thej. The number of farmers growing those varieties, however, was negligible except for Heera-2 (HS-273). Out of these varieties, only Sonar bangla and Heera-2 (HS-273) were found to have been growing since the beginning. From the last cropping season (2010 boro seaon) farmers adopted some new varieties. These were: Arize Dhani (H-07002), BRRI Hybrid dhan-3, Falan (GH-12), Heera-6 (HS 48), Jamuna, Ropushe Bangla-1, Rupali-7 (GB-0102) and Shera (BRS 696). It is possible that those newly arrived varieties gave farmers an opportunity to replace previous varieties with which they were not satisfied. These were Kothayrakhi, Krishan, Shakti, Shufala, Surma and Trifa. It is found that these varieties had been adopted few years ago but were no longer in practice in recent times.

Two varieties, namely Shakti and Kothayrakhi, which were not approved by NSB, were also found under cultivation. This is an alarming indication because neither these varieties went through on farm trial and nor their performance have been evaluated. Cultivating such unapproved varieties may cause devastation at the farmers' field. 
Table 2. Varietal information of hybrid rice cultivated over a decade

\begin{tabular}{|c|c|c|c|c|c|c|c|c|c|c|c|}
\hline Variety & $\begin{array}{c}2011 \\
(n=224)\end{array}$ & $\begin{array}{c}2010 \\
(n=262)\end{array}$ & $\begin{array}{c}2009 \\
(n=259)\end{array}$ & $\begin{array}{c}2008 \\
(n=176)\end{array}$ & $\begin{array}{c}2007 \\
(n=133)\end{array}$ & $\begin{array}{c}2006 \\
(\mathrm{n}=68)\end{array}$ & $\begin{array}{c}2005 \\
(n=30)\end{array}$ & $\begin{array}{c}2004 \\
(n=14)\end{array}$ & $\begin{array}{l}2003 \\
(n=4)\end{array}$ & $\begin{array}{l}2002 \\
(n=4)\end{array}$ & $\begin{array}{l}2001 \\
(n=1)\end{array}$ \\
\hline AALOK-93024 & - & $1(0.38)$ & - & $2(1.14)$ & $4(3.01)$ & $4(5.88)$ & $2(6.67)$ & $3(21.43)$ & - & - & - \\
\hline ACI-1 & $10(4.46)$ & $15(5.73)$ & $17(6.56)$ & $10(5.68)$ & $11(8.27)$ & $3(4.41)$ & $1(3.33)$ & - & - & - & - \\
\hline ACI-2 & $15(6.70)$ & $13(4.96)$ & $14(5.41)$ & $7(3.98)$ & $5(3.76)$ & $3(4.41)$ & $1(3.33)$ & - & - & - & - \\
\hline Agamoni & $4(1.79)$ & $4(1.53)$ & $1(0.39)$ & - & - & - & - & - & - & - & - \\
\hline \multicolumn{12}{|l|}{ (JBS-17-4) } \\
\hline Agrani 7 (HRM-01) & $3(1.34)$ & $6(2.29)$ & $3(1.16)$ & $1(0.57)$ & $1(0.75)$ & $1(1.47)$ & - & - & - & - & - \\
\hline Alloran-2 (HB-09) & $4(1.79)$ & $5(1.91)$ & $7(2.7)$ & $5(2.84)$ & $2(1.50)$ & $3(4.41)$ & $1(3.33)$ & - & - & - & - \\
\hline Arize Dhani (H-07002) & $19(8.48)$ & $4(1.53)$ & - & - & - & - & - & - & - & - & - \\
\hline Arize Tej (96110) & $17(7.59)$ & $12(4.58)$ & $3(1.16)$ & $1(0.57)$ & - & - & - & - & - & - & - \\
\hline Agro G-2 (Bijli & $1(0.45)$ & $2(0.76)$ & $3(1.16)$ & - & - & - & - & - & - & - & - \\
\hline \multicolumn{12}{|l|}{ EAL9202) } \\
\hline BRRI Hybrid dhan-3 & $2(0.89)$ & $1(0.38)$ & - & - & - & - & - & - & - & - & - \\
\hline Chamak-1 & $1(0.45)$ & $3(1.15)$ & - & $1(0.57)$ & - & - & - & - & - & - & - \\
\hline Falan (GH-12) & $5(2.23)$ & $1(0.38)$ & - & - & - & - & - & - & - & - & - \\
\hline Gold (HTM-606) & $3(1.34)$ & $3(1.15)$ & $3(1.16)$ & $2(1.14)$ & $3(2.26)$ & $2(2.94)$ & $1(3.33)$ & - & - & - & - \\
\hline Heera-1 & $9(4.02)$ & $10(3.82)$ & $13(5.02)$ & $8(4.55)$ & $7(5.26)$ & $1(1.47)$ & - & 2 14.29) & - & - & - \\
\hline Heera-2 (HS-273) & $71(31.70)$ & $111(42.37)$ & $146(56.37)$ & $103(58.52)$ & $68(51.13)$ & $39(57.35)$ & $9(30)$ & $2(14.29)$ & $1(25)$ & $1(25)$ & - \\
\hline Heera-5 & $8(3.57)$ & $11(4.20)$ & $14(5.41)$ & $6(3.41)$ & $6(4.51)$ & $3(4.41)$ & $3(10)$ & - & - & - & - \\
\hline Heera-6 (HS 48) & $1(0.45)$ & - & - & - & - & - & - & - & - & - & - \\
\hline Jagoron & $4(1.79)$ & $4(1.53)$ & $8(3.09)$ & $4(2.27)$ & $4(3.01)$ & $6(8.82)$ & $6(20)$ & 321.43 ) & - & - & - \\
\hline Jamuna & - & $3(1.15)$ & - & - & - & - & - & - & - & & - \\
\hline Agro G-1 (Jhalak & $3(1.34)$ & $21(8.02)$ & $10(3.86)$ & $3(1.7)$ & $5(3.76)$ & $3(4.41)$ & $1(3.33)$ & - & - & - & - \\
\hline \multicolumn{12}{|l|}{ EAL9201) } \\
\hline Kothayrakhi & - & - & -- & - & $1(0.75)$ & - & - & - & - & - & - \\
\hline Krishan & - & - & - & $1(0.57)$ & - & - & - & - & - & - & - \\
\hline Aftab L.P. 50 & - & - & - & - & $2(1.50)$ & $1(1.47)$ & $1(3.33)$ & - & - & - & - \\
\hline Aftab L.P. 106 & $4(1.79)$ & $8(3.05)$ & $4(1.54)$ & $2(1.14)$ & - & $1(1.47)$ & - & - & - & - & - \\
\hline Aftab L.P. 70 & 5.(2.23) & $4(1.53)$ & $4(1.54)$ & $4(2.27)$ & $3(2.26)$ & $1(1.47)$ & $1(3.33)$ & - & - & - & - \\
\hline Madhumoti & - & $1(0.38)$ & $1(0.39)$ & $1(0.57)$ & - & - & - & - & - & - & - \\
\hline Moyna (HTM-303) & $3(1.34)$ & $8(3.05)$ & $5(1.93)$ & $5(2.84)$ & - & - & - & - & - & - & - \\
\hline Rajkumar (GH-14) & $3(1.34)$ & $4(1.53)$ & $1(0.39)$ & $1(0.57)$ & - & - & - & - & - & - & - \\
\hline RICER-101 & $2(0.89)$ & $7(2.67)$ & $9(3.47)$ & $9(5.11)$ & $8(6.02)$ & $5(7.35)$ & $3(10.00)$ & $1(7.14)$ & - & - & - \\
\hline Ropushe Bangla-1 & $6(2.68)$ & $4(1.53)$ & - & - & - & - & - & - & - & - & - \\
\hline Rupali-7 (GB-0102) & $8(3.57)$ & $7(2.67)$ & - & - & - & - & - & - & - & - & - \\
\hline Shakti & - & $1(0.38)$ & - & $1(0.57)$ & - & - & - & - & - & - & - \\
\hline Sampad (93024) & $14(6.25)$ & $8(3.05)$ & $2(0.77)$ & $2(1.14)$ & $1(0.75)$ & - & - & - & - & - & - \\
\hline Sanker-3 (Hejia-909) & $1(0.45)$ & $1(0.38)$ & $1(0.39)$ & - & - & - & - & - & - & - & - \\
\hline Shathi & $5(2.23)$ & $5(1.91)$ & $6(2.32)$ & $1(0.57)$ & - & - & - & - & - & - & - \\
\hline Shera (BRS 696) & $5(2.23)$ & $3(1.15)$ & - & - & - & - & - & - & - & - & - \\
\hline Shufala & - & - & - & $1(0.57)$ & - & - & - & - & - & - & - \\
\hline SL 8H Hybrid dhan & $26(11.61)$ & $14(5.34)$ & $5(1.93)$ & $1(0.57)$ & - & - & - & - & - & - & - \\
\hline Sonar Bangla & $4(1.79)$ & $2(0.76)$ & $8(3.09)$ & $10(5.68)$ & $14(10.53)$ & $6(8.82)$ & $5(16.67)$ & $3(21.43)$ & $3(75)$ & $3(75)$ & $1(100)$ \\
\hline Surma & - & - & $5(1.93)$ & $2(1.14)$ & $2(1.5)$ & - & - & - & - & - & - \\
\hline Tia (HTM-707) & $10(4.46)$ & $6(2.29)$ & $9(3.47)$ & $5(2.84)$ & $3(2.26)$ & $1(1.47)$ & - & - & & - & - \\
\hline Trifa & - & - & - & $1(0.57)$ & - & - & - & - & - & - & - \\
\hline
\end{tabular}

Note: Figure in parentheses indicate percentage of the respondents. 


\subsection{Highest Performing Varieties of Hybrid Rice}

Figure 3 clearly demonstrates that farmers rated 13 varieties as the best performing varieties in their field. These were, according to the order of performance, Heera-2 (HS-273) (41.33\%), SL 8H Hybrid dhan (6.07\%), Arize Thej (5.2\%), Arize Dhani (3.76\%), ACI-2 (3.47\%), RICER-101 (3.18\%), ACI-1 (3.18\%), Tia (HTM-707) (2.89\%), Heera-1 (2.6\%), Heera-5 (2.02\%), Sampad (1.45\%), Sonar Bangla (1.45\%) and then Moyna (1.16\%). Out of these, the outstanding variety in view of the farmers is Heera -2 .

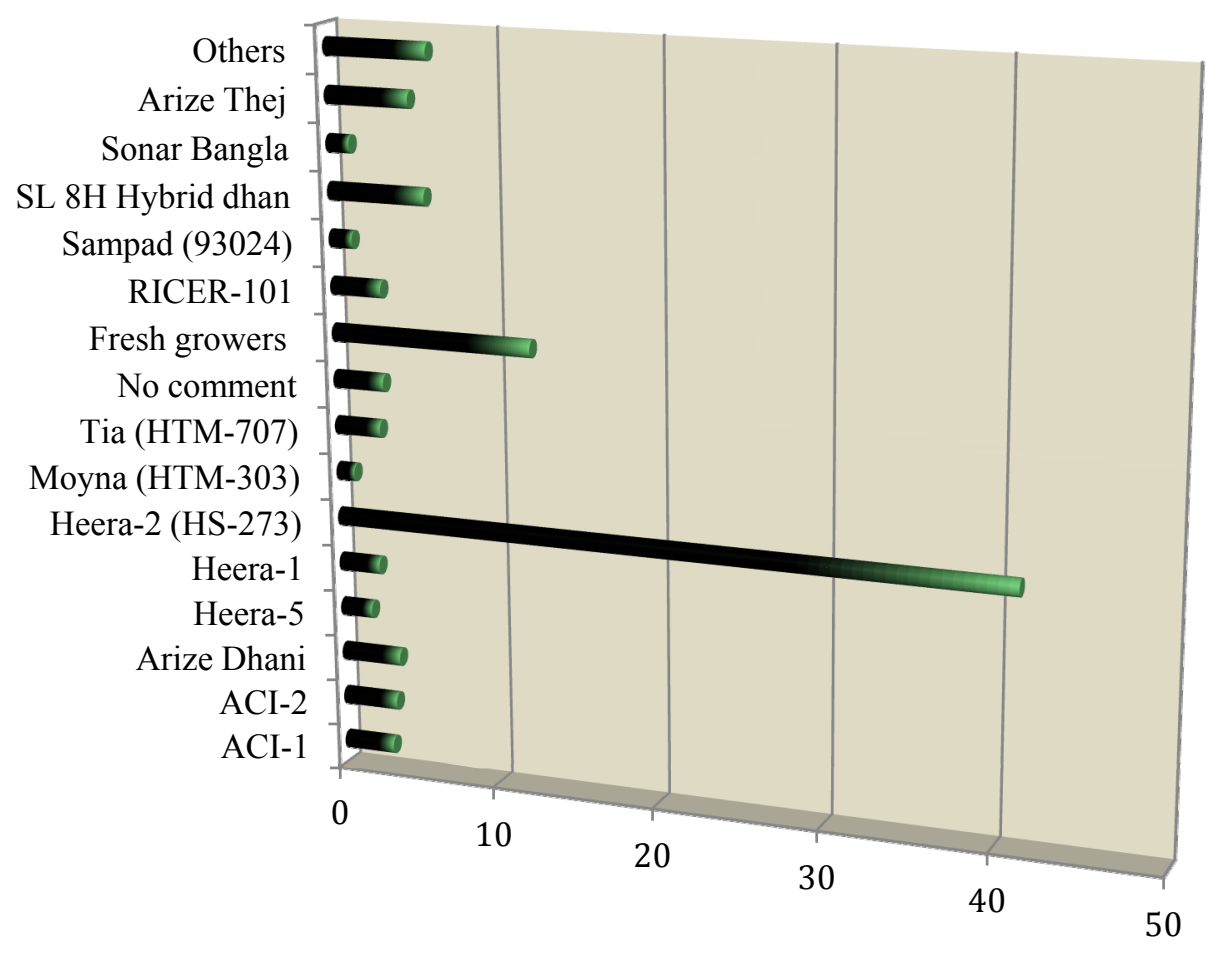

Figure 3. Highest performing varieties of hybrid rice

In addition, there were three other categories: no comment, fresh growers, and others. In the fresh grower category, there were $12.43 \%$ growers who grew hybrid rice for the first time. They therefore did not have sufficient scope to evaluate which one is best. Another $3.18 \%$ of growers did not give their opinion. They argued that it depends upon the cultivation procedure and climatic conditions. If these are properly cultivated maintaining recommended procedures such as seedling age, spacing, number of seedlings per hill, proper dose, time and method of application and do not face any natural hazard, then all goes well. The third category was composed of $6.38 \%$ of the growers, who had chosen one of the following varieties as their best variety: Agrani 7 (HRM-01), Agro G-1 (Jhalak EAL9201), Agro G-2 (Bijli EAL9202), Jagoron, Jamuna, Lp 106, Lp 70, Rajkumar (GH-14), Rupali-7 (GB-0102), Shathi, Shera (BRS 696) and Surma.

\subsection{Extent of Adoption of Hybrid Rice}

Considering the extent of adoption of hybrid rice during the period of 2001-2011 boro seasons, the de-adopters and continuing adopters ranged from $0.83-100 \%$ of the potential area and $4.52-100 \%$ of the potential area, with averages of $38.40 \%$ and $37.56 \%$ and a standard deviation of 25.03 and 21.52 , respectively. Based on the extent of adoption, each group of de-adopters and continuing adopters is further categorized into three, shown in Table 3. 
Table 3. Distribution of the respondents according to their extent of adoption of hybrid rice during the period of 2001-2011 boro seasons

\begin{tabular}{llll}
\hline Category & De-adopters & Continuing adopters & Total \\
\hline Lower level adoption $\left(\leq 33.32 \% \mathrm{PL}^{*}\right)$ & $67(54.9)$ & $104(46.4)$ & $171(49.4)$ \\
Moderate level adoption $(33.33-66.66 \%)$ & $36(29.5)$ & $95(42.4)$ & $131(37.9)$ \\
Higher level adoption $(\geq 66.67 \%)$ & $19(15.6)$ & $25(11.2)$ & $44(12.7)$ \\
Total & $122(100)$ & $224(100)$ & $346(100)$ \\
\hline Descriptive statistics & & & \\
Minimum & 0.83 & 4.52 & 0.83 \\
Maximum & 100.00 & 100.00 & 100.00 \\
Mean & 38.40 & 37.56 & 37.86 \\
Standard deviation & 25.03 & 21.52 & 22.79
\end{tabular}

$\mathrm{PL}^{*}$ indicates Potential land; Figure in parentheses indicates percentage; $\mathrm{t}(219)=0.312^{\mathrm{NS}}, \mathrm{P}=0.75$; ${ }^{\mathrm{NS}}$ Indicates non-significant.

As shown in Table 3, the computed $t$ value is 0.312 with 219 degrees of freedom at 0.75 level of probability indicating that de-adopters and continuing adopters are not significantly different in terms of the extent of adoption of hybrid rice.

Table 3 also reveals that the highest proportion both of de-adopters (54.9\%) and continuing adopters (46.4\%) had a lower level adoption of hybrid rice. It is surprising to note that the proportion of de-adopters abruptly reduced to $29.5 \%$ for practicing moderate level adoption of hybrid rice while for the continuing adopters the proportion $(42.4 \%)$ remained approximately constant. With regard to the higher-level adoption, both de-adopters and continuing adopters reduced to $15.6 \%$ and $11.2 \%$, respectively. Merging the above two categories it is found that, about $84 \%$ de-adopters and $89 \%$ adopters cultivated hybrid rice on lower to moderate proportions of their potential land. So, the point is farmers are still afraid of going for large-scale adoption of hybrid rice.

\subsection{District-Wise Extent of Adoption of Hybrid rice}

The extent of adoption of hybrid rice in Habignaj, Laksmipur, Magura, Naogoan and Nilpamari ranged from $4.54-100 \%, 7.81-100 \%, 0.83-93.75 \%, 5.79-100 \%, 4.52$ to $100 \%$ and 4.52 to $100 \%$ of potential area with averages of $36.07 \%, 43.48 \%, 31.73 \%, 36.92 \%$, and $37.56 \%$ and a standard deviation of $20.46,26.91,17.89$, $23.72, \& 22.67$, respectively. Based on the extent of adoption, district-wise growers are further categorized (Table 4).

Table 4. District-wise distribution of the respondent according to the extent of adoption of hybrid rice

\begin{tabular}{lllllll}
\hline \multirow{2}{*}{ Category } & \multicolumn{5}{c}{ Selected district } & \multirow{2}{*}{ Total } \\
\cline { 2 - 6 } & Habiganj & Laksmipur & Magura & Naogoan & Nilphamari & \\
\hline $\begin{array}{l}\text { Lower level adoption } \\
\left(\leq 33.32 \% \text { of } \text { PL }^{*}\right)\end{array}$ & $36(52.2)$ & $32(45.1)$ & $41(58.6)$ & $36(52.9)$ & $26(38.2)$ & $171(49.4)$ \\
$\begin{array}{l}\text { Moderate level adoption. } \\
(33.33-66.66 \%)\end{array}$ & $26(37.7)$ & $24(33.8)$ & $27(38.6)$ & $23(33.8)$ & $35(51.5)$ & $135(39.0)$ \\
$\begin{array}{l}\text { Higher level adoption } \\
(\geq 66.67 \%)\end{array}$ & $7(10.1)$ & $15(21.1)$ & $2(2.9)$ & $9(13.2)$ & $7(10.3)$ & $40(11.6)$ \\
Total & $69(100)$ & $71(100)$ & $70(100)$ & $68(100)$ & $68(100)$ & $346(100)$ \\
\hline $\begin{array}{l}\text { Descriptive statistics } \\
\text { Minimum }\end{array}$ & 4.54 & 7.81 & 0.83 & 5.79 & 4.52 & 0.83 \\
Maximum & 100 & 100 & 93.75 & 100 & 100 & 100 \\
Mean & 36.07 & 43.48 & 31.73 & 36.92 & 41.07 & 37.86 \\
Standard deviation & 20.46 & 26.91 & 17.89 & 23.72 & 22.67 & 22.79 \\
\hline
\end{tabular}

Note: $\mathrm{PL}^{*}$ indicates Potential land: Figure in parentheses indicates percentage of the respondents. 
Table 4 also shows that out of the five, Nilphamari is a single district where a majority of the farmers (51.5\%) practiced moderate level adoption of hybrid rice. The highest proportion of the respondents in all other four districts viz., Magura (58.6\%), Naogoan (52.9\%), Habignaj (52.2\%), and Laksmipur (45.1\%) were found to operate their land with a lower level of adoption, followed by a moderate level of adoption. The lowest proportion of the respondents in Magura (2.9\%), Habignaj (10.1\%), Nilpamari (10.3\%) Naogoan (13.2\%) and Laksmipur (21.1\%) had a higher-level adoption of hybrid rice. The findings indicate that still there is an enormous potential for improving the level of adoption of hybrid rice even amongst continuing adopters.

\subsection{Year-Wise Average Adoption of Hybrid Rice}

Although at the beginning in the season of 2001-2002 the mean adoption was about $17.63 \%$ of potential land, it abruptly dropped down at $6.74 \%$ in following year of 2002-2003, as is shown in Figure 4.

With a sudden increase of $11.11 \%$, the decline was recovered and resulted in $17.85 \%$ in the following season, 2003-2004. From this point the average adoption rate reached $40.93 \%$ in a tortuous fashion during $2010-2011$. However, the significant rise (about 11\%) was found in two alternate seasons: 2003-2004 and 2005-2006 simply because of the outstanding field performance of hybrid rice. But what happened to the cropping season 2002-2003 and 2006-2007, and 2011-2012 with regard to declining adoption rate? Undesired output performance mainly caused by a crop disaster, in particular forming unfilled grains, was one of the leading factors for the sudden fall in adoption. With reference to this finding it may be cited that the managing director of 'Channel I', Siraj (2012) telecasted a live program on hybrid rice on 20 April from Muktagacha subdistrict under Mymensingh district. The program captured a total picture of the devastating situation of hybrid rice caused by the formation of unfilled grains. About $60 \%$ panicles were found converted into empty grains. Farmers identified a couple of reasons for such a disastrous performance: lack of pure seeds (variety) at the government level and fraudulent behavior of unscrupulous seed dealers with the farmers. In response to the inconsistent rate of adoption, one of the farmers reported that "adoption rate of hybrid rice depends on its performance: if it performs well, the rate increases while the worst performance decelerates the rate in the following cropping season".

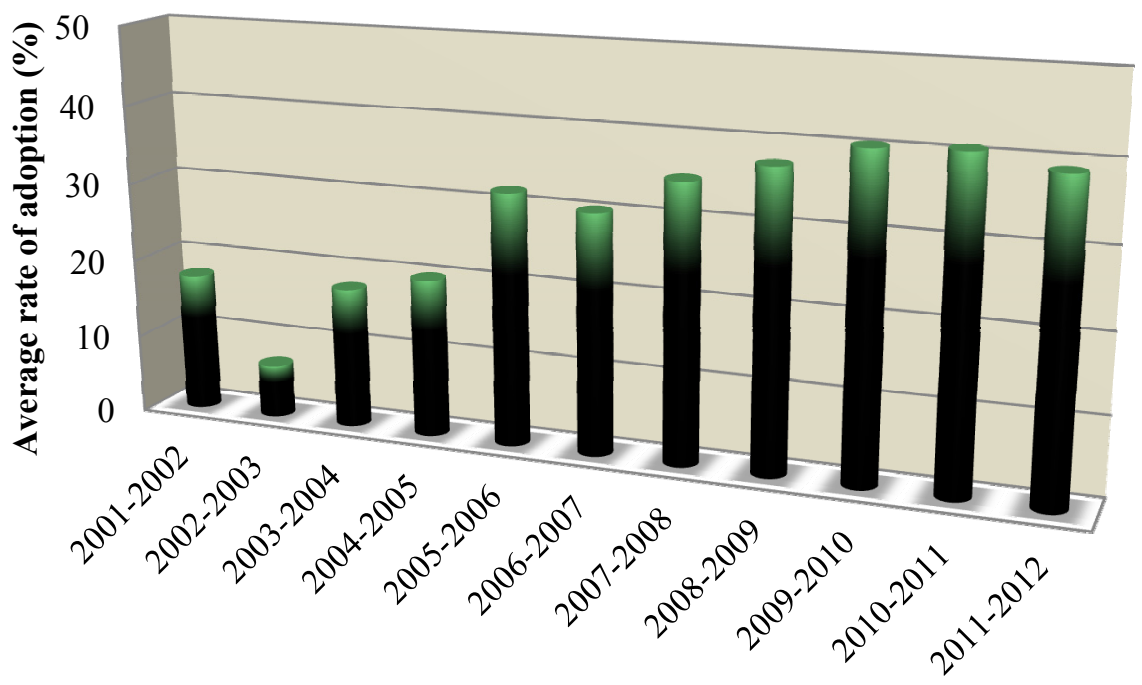

Figure 4. Year-wise adoption of hybrid rice

\subsection{Determinants of Hybrid Rice Adoption}

A logistic regression analysis was conducted to predict farmers' decision to adopt hybrid rice (where 1=adopted hybrid rice, perhaps rejecting later on, and $0=$ has never adopted hybrid rice) for 425 respondents (79 non-adopters and 346 adopters) using age, education, family size, farm size, total annual income (in 000's BDT), membership in social organization, training status, communication exposure, promotional effort, risk perception, and attitude towards hybrid rice as predictors. Several of these variables did not make a significant contribution 
to the variation in the adoption of hybrid rice. However, we attempted to remove non-significant variables from the full model and refit the model using only the constant, education, annual family income (thousand BDT), communication exposure and attitude towards hybrid rice in order to avoid the effect of non-significant variables on the coefficients of the significant variables. The output analysis of the reduced model is presented in Table 5. In the reduced model, Chi Square has 4 degrees of freedom, a value of 51.879 and a probability of $\mathrm{P}<0.000$ indicating that the model that has been fitted is accurate. Nagelkerke's $\mathrm{R}^{2}$ of .19 indicated a moderate level relationship between prediction and grouping. The model suggested that the overall prediction success was $79.1 \%$ $(\mathrm{n}=425)$, but $17.7 \%$ for non-adopters $(\mathrm{n}=79)$ and $93.1 \%$ for adopters $(\mathrm{n}=346)$ were correctly predicted where the cutoff is 0.6. The Hosmer and Lemeshow goodness-of-fit test statistic was greater than .05 (chi square $=12.282$, $\mathrm{p}=.139$ with $8 \mathrm{df}$ ), indicating that the model fits the data at an acceptable level.

The logistic regression results revealed that educational achievement was a significant predictor $(p=.036)$, which adversely influenced farmers' willingness to adopt hybrid rice (Table 5). It indicates respondents with a low level of education were more willing to adopt hybrid rice than the respondents with a high level of education. For this study the 0.932 odds ratio for education indicates that the odds of adopting hybrid rice decreased by $7 \%$ for each extra year of education when all other explanatory variables are held constant. This finding is in conformity with the findings of Mendola (2007) on the adoption of agricultural technology in Bangladesh, and Masangano, and Miles (2004) on the adoption of kalima bean in Malawi. Nevertheless, some previous findings contrast this result by stating that education and new technology adoption are positively correlated, as cited by Kabir, Yegbemey, and Bauer (2013); Fleke and Zegeye (2006) in the adoption of improved maize varieties in southern Ethiopia; Gershon, Just, and Zilberman (1985), Gerhart (1975) in the adoption of hybrid maize in Kenya; Rosenzweig (1978) in the adoption of high-yield grain in the Punjab; Jamison and law (1982) in the adoption of chemical inputs in Thailand.

Table 5. Logistic regression results after fitting the reduce model of four predictive variables on farmers' decision in adopting hybrid rice $(\mathrm{N}=425)$

\begin{tabular}{lccccc}
\hline Variables & B & S.E. & Wald & Sig. & Exp(B) \\
\hline Education & -.070 & .033 & 4.414 & .036 & .932 \\
Annual family income (000’ BDT) & .003 & .001 & 11.009 & .001 & 1.003 \\
Communication exposure & .055 & .018 & 9.840 & .002 & 1.057 \\
Attitude towards hybrid rice & .068 & .019 & 13.301 & .000 & 1.071 \\
Constant & -3.657 & .960 & 14.506 & .000 & .026 \\
\hline
\end{tabular}

\begin{tabular}{ll}
\hline Model summary & 356.288 \\
-2 Log likelihood & 51.879 with $4 \mathrm{df}(\mathrm{P}<0.000)$ \\
$\quad$ Chi square & 0.19 \\
Nagelkerke's $\mathrm{R}^{2}$ & 12.282 with $8 \mathrm{df}(\mathrm{P}>0.05)$ \\
Hosmer -Lemeshow test & $79.1 \%$
\end{tabular}

* indicates significant at $5 \%$ level $(0.01<\mathrm{p}<0.05)$; ** indicates significant at $1 \%$ level $(0.001<\mathrm{p}<0.01)$; *** indicates significant at $0.1 \%$ level $(\mathrm{p}<0.00)$.

Although it sounds contradictory that increment of education leads to a decrease in adoption of hybrid rice, anecdotal support was found for this in the study area. The chance of being involved in farming gets reduced with increasing education. Usually those involved in farming in Bangladesh are mostly illiterate or partially literate. They live on farming. Instead, educated people are mainly involved in the other professions (e.g. Government or Non-government job) ignoring farming as a primary occupation. If they are still involved in farming, they cultivate their land through tenant farmers: they seldom cultivate their land on their own. Farming decisions are usually thus made by the education de-oriented practicing farmer. Hence, the lower the educational level the higher the concentration on farming.

Data presented in Table 5 also shows that annual family income was a significant predictor $(p=.001)$, which positively influenced farmers' willingness to grow hybrid rice. The finding implies that the higher the family 
income, the better the chance of adoption. In this study, when annual income is raised by one thousand BDT the odds of adopting hybrid rice increase by $0.3 \%$ when all other explanatory variables are held constant. This finding support the findings of other empirical studies carried out by Sarker et al. (2005) on the adoption of organic farming; Kabir, Yegbemey, and Bauer (2013) on the adoption of Biogas in Bangladesh; Tambo \& Abdoulaye (2011) on the adoption of drought tolerant maize variety in Nigeria; Udensi et al. (2011) on the adoption of Cassava varieties in south-eastern Nigeria; and Napier and Bridges (2003) on the adoption of conservation production system within the upper region of the Scioto ricer watershed in Ohio.

The implication of this finding is that the technology is less accessible to resource-poor farmers because of financial and resource constraints that inhibit their ability to purchase the seed of this technology and its complementary inputs. It requires higher amounts of complementary inputs, especially fertilizer and pesticides, and irrigation on time. In order to cultivate in one hectare of land, the total cost of inputs was about 23 percent higher for hybrids than for HYVs. In particular farmers struggle with about four times higher seed cost (Hossain, Janaiah, \& Husain, 2003). Farmers with higher incomes are more likely to have the necessary funds to finance the initial cost, for instance, buying seeds, and subsequent farm operations e.g., applying fertilizer, pesticides and irrigation and so on. In addition hybrid rice is risky as the crop may get damaged with biotic (insects and diseases) and abiotic (hailstorm and flash flood) stresses. Farmers experiencing this daunting situation may abstain from adoption of hybrid rice or reject the same for further continuation. But still the farmers who are wealthy go with hybrid rice to take advantages of its higher yield. So, the above finding reflects the fact that farmers with higher incomes are more likely to adopt the risky technology compared with those with a low income (Batz et al., 1999; Kivlin \& Filegel, 1966) as cited in Sarker et al. (2005). Thus, higher adoption of hybrid rice commensurate with high income is a reality. The finding suggests that the existence of a capital barrier needs to be removed by offering subsidies to the resource-poor farmers in order to facilitate access to the technology.

Table 5 also revealed that communication exposure was a significant predictor $(p=.002)$ in adoption of hybrid rice. This finding indicates that there was a concomitant increases in adoption with the increase of communication exposure. For this study, a one-point increase in the score of communication exposure was associated with odds of adopting hybrid increasing by $5.5 \%$ while holding all other variables constant. This result are quite similar to some other adoption studies as conducted by Sarker et al. (2005) and Tambo and Abdoulaye (2011).

Extension support from DAE or any other private sources enhances the promotion of the technology through the provision of advice, information and technical support to farmers. Farmers contacting with mass media such as Radio and TV become aware of hybrid rice technology by watching agricultural programs. Consulting with neighboring farmers, they start a trial and consequently adopt the technology. In particular, farmers who communicated with SAAO in their block are always guided through useful information for cultivating hybrid rice that in turn results in higher production. Likewise, dealers are also key information sources prompting hybrid rice cultivation in the locality. Farmers maintaining good contact with these sources are properly guided through variety selection and other recommended procedure that is found to have a tremendous influence on production. On the other hand, farmers who are reluctant to contact dealers are sometimes swindled into buying faulty seeds that result in a catastrophe. So, the higher the communication exposure to information sources and channels, the greater the adoption of hybrid rice.

One major variable of interest is attitude towards cultivating hybrid rice, and this is highly significant $(p=.000)$ and positively influences the decision to adopt hybrid rice technology (Table 4). So, the finding indicates that higher scores on attitude correlate with bigger scores on adoption, which means farmers having favorable attitudes were more likely to adopt hybrid rice. It was found in this study that the odds ratio for attitude is 1.071 meaning that for each one-point increase in the attitudinal scale there is a $6.8 \%$ increase in the odds of adopting hybrid rice when all other explanatory variables are held constant. Farmers' attitudes towards hybrid rice technology are a significantly dominating factor in terms of adoption decisions. It has been reported that farmers' attitudes towards new technology, particularly the perception of new varieties, are widely hypothesized to be influential in the adoption decision (Poolsawas \& Napasintuwong, 2013). Result of the econometric model indicated that the household head's attitude towards a haricot bean production technology package was an important variable which had positively and significantly influenced adoption and intensity of adoption of improved haricot bean production package (Negash, 2007). It is logical to expect that if a farmer shapes up with a positive attitude towards cultivation procedures (associated costs for required complementary inputs, and to the yield level of hybrid rice) the farmer is more likely to adopt hybrid rice. 


\section{Conclusions and Implication}

In the light of the foregoing discussion about the adoption status of hybrid rice in Bangladesh, the following conclusions are drawn:

a) No significant difference was found between non-adopters, de-adopters and continuing adopters as to age, educational qualification, training experience and membership in social organizations. A significant difference, however, was found between de-adopters and continuing adopters in terms of family size, farm size, annual family income, communication exposure, assessment of promotional activities, perception of risk, and attitude towards hybrid rice.

b) Out of 99 recommended varieties only 40 varieties have been cultivated at the field level to a varying extent. The highest proportion of the farmers rated Heera- 2 as the best performing variety. Two unapproved varieties were also found to be cultivated.

c) Data also confirmed that the overall extent of adoption of hybrid rice during the period of 2001-2011 boro seasons was relatively low in the sample areas. The highest proportion of the de-adopters $(55 \%)$ and continuing adopters $(46.4 \%)$ were found to have a lower level adoption $(\leq 33.32 \%$ of potential area) of hybrid rice. Out of five districts, a higher level of adoption was found in Laksmipur (43.48\%) and Nilphamari (41.07\%). The mean adoption was 17.63 percent in the 2001 boro season, and then it increases in a tortuous fashion and culminates in $40.93 \%$ in 2010 boro season.

d) The computed t value indicates that de-adopters and continuing adopters are not significantly different in term of the extent of adoption of hybrid rice. Logistic regression results, after fitting the full model of 11 selected predictive variables on farmers' decisions in adopting hybrid rice, showed that education, annual family income, communication exposure, and attitude towards hybrid rice made significant contributions to farmers' decisions in adopting hybrid rice.

There is an enormous potential for improving the level of adoption of hybrid rice. Once informed about the current status of hybrid rice, the Government of Bangladesh has the opportunity to refine policy guidelines addressing the following areas: first, to establish or strengthen the key linkages and/or interrelationships among the stakeholders such as the Department of Agricultural Extension (DAE), the Bangladesh Rice Research Institute (BRRI), the Bangladesh Agricultural Development Corporation (BADC), seed companies, dealers, and farmers in the diffusion of hybrid rice. Second, after assessing the status of varietal information, the concerned authorities might research the impediments farmers face in cultivating their varieties. Finally, the authority can make a significant impact on hybrid rice cultivation by recommending the right variety. In doing so, the field level extension workers, in particular, Sub Assistant Agriculture Officers (SAAO) might guide farmers to select the right variety and go through the recommended procedure.

\section{Acknowledgements}

The authors are grateful to the participant farmers for their time and interest. They would also like to acknowledge the sincere cooperation of the personnel working under the Department of Agricultural Extension (DAE), in particular Upazila staff, especially the Upazila Agricuture Officer (UAO) and Sub-assistant Agricultural Extension Officer (SAAOs) for guiding the first author in the conduction of the fieldwork. The work was supported by DEEWR, (Australian Federal Government) who awarded an Endeavour Postgraduate Award to the first author, and the International Crops Research Institute for the Semi-Arid Tropics (ICRISAT), Patancheru 502 324, Andhra Pradesh, India for providing a research grant to conduct fieldwork on "Diffusion and Adoption of Hybrid Rice in Bangladesh", from which the present article is derived.

\section{Reference}

Ahmed Khan, M., Ziaul Karim, A. S. M., Jeong, K. H., Kim, E. J., \& Rahman, M. (2013). Adopter Categories in Respect to a Transplanted Monsoon Rice Variety in two Selected Villages of Bangladesh. Journal of Agricultural Science, 5(3), 200-216. http://dx.doi.org/10.5539/jas.v5n3p200

Awal, M. A., \& Siddique, M. A. B. (2011). Rice Production In Bangladesh Employing by Arima Model. Bangladesh Journal of Agricultural Research, 36(1), 51-62.

Babbie, E. (1990). Survey Research Methods (2nd ed.). Belmont, CA: Wadsworth.

BBS. (2011). Yearbook of Agricultural Statistics of Bangladesh. Ministry of Agriculture, GoB, Dhaka.

Corbetta, P. (2003). Social Research: Theory, Methods and Techniques. London: Sage.

Creswell, J. W. (2009). Research Design: Qualitative, Quantitative, and Mixed Methods Approaches (3rd ed., p. 5). Thousand Oaks, CA: Sage. 
Dillman, D. A. (2007). Reduction of Coverage and Sampling Error. In Mail and Internet Surveys: The Tailored Design Method (2nd ed.). Hoboken, New Jersey: John Wiley \& Sons.

Feder, G., Just, R. E., \& Zilberman, D. (1985). Adoption of Agricultural Innovations in Developing Countries: A Survey. Economic Development and Cultural Change, 33(2), 255-298.

Fleke, S., \& Zegeye, T. (2006). Adoption of Improved Maize Varieties in Southern Ethiopia: Factors and Strategy Options. Food Policy, 31, 442-457.

Ganesh-Kumar, A., Prasad, S. K., \& Pullabhotla, H. (2012). Supply and Demand for Cereals in Bangladesh, 2010-2030 (IFPRI Discussion Paper 01186). New Delhi.

GoB. (2003). Bangladesh Gazette (p. 64). Bangladesh: Bangladesh Gazzette.

Hossain, M., Janaiah, A., \& Husain, M. (2003). Hybrid Rice in Bangladesh: Farm-Level Performance. Economic and Political Weekly, 38(25), 2517-2522.

Hossain, M. Z. (2011). A Handout on List of Crop Vrieties Approved By Nation Seed Board till September/2011. Seed Cerification Agency, Gazipur.

Hubbard, W. G., \& Sandmann, L. R. (2007). Using Diffusion of Innovation Concepts for Improved Program Evaluation. Journal of Extension (Vol. 45).

Israel, G. (2009, April). Determining Sample Size. \#PEOD6, 1-5.

Jegede, O. C., Bolorunduro, P. I., \& Ikani, E. I. (2007). Levels of Awareness and Adoption of Disseminated Livestock Technologies in Enugu state, Nigeria. Journal of Food, Agriculture and Environment, 5(2), 185-188.

Julfiquar, A. W. (2002). Hybrid Rice Research and Development in Bangladesh: Hybrid Rice for Food Security. In Poverty Alleviation and Environmental Protection (pp. 235-245). Hanoi, Vietnam.

Kabir, H., Yegbemey, R. N., \& Bauer, S. (2013). Factors Determinant of Biogas Adoption in Bangladesh. Renewable and Sustainable Energy Reviews, 28, 881-889. http://dx.doi.org/10.1016/j.rser.2013.08.046

Mackrell, D., Kerr, D., \& Hellens, L. von. (2009). A Qualitative Case Study of the Adoption and Use of an Agricultural Decision Support System in the Australian Cotton Industry: the Socio-Technical View. Decision Support Systems, 47(2), 143-153. http://dx.doi.org/10.1016/j.dss.2009.02.004

Marasas, C. N., Anandajayasekeram, P., Millard, S., \& Rooyen, C. J. va. (2006). Farm-Level Adoption and Impact of Agricultural Technology: the case of Russian Wheat Aphid Resistant Cultivars in South Africa. S. Afr. J. Agric. Ext., 34(2), 318-333.

Masangano, C. M., \& Miles, C. A. (2004). Factors Influencing Farmers' Adoption of Kalima Bean ( Phaseolus vulgaris L.) Variety in Malawi. Journal of Sustainable Agriculture, 24(2), 117-129. http://dx.doi.org/10.1300/J064v24n02

McFall, W., Magnan, N., \& Spielman, D. (2013). Hybrid Rice as a Pro-Poor Technology? Evidence from Bangladesh. In Agricultural \& Applied Economics Association's 2013 AAEA \& CAES Joint Annual Meeting, Agusutst 4-6,. Washington, DC.

Mendola, M. (2007). Agricultural Technology Adoption and Poverty Reduction: A Propensity-Score Matching Analysis for Rural Bangladesh. Food Policy, 32(3), 372-393.

Miller, M., Mariola, M., \& Hansen, D. (2008). EARTH to farmers: Extension and the adoption of environmental technologies in the humid tropics of Costa Rica. Ecological Engineering, 34(4), $349-357$. http://dx.doi.org/10.1016/j.ecoleng.2007.05.009

Napier, T. L., \& Bridges, T. (2003). Adoption of Conservation Production Systems within the Upper Region of the Scioto Ricer Watershed in Ohio. Journal of Food, Agriculturre \& Environment, 1(2), 287-294.

Negash, R. (2007). Determinants of Adoption of Improved Haricot Bean Production Package in Alaba Special Woreda, Southern Ethiopia. HARAMAYA UNIVERSITY.

Nirmala, B., \& Suhasini, K. (2013). Farmer's Experience with Hybrid Rice Technology: A Case Study of Khunti District of Jharkhand State of India. African Journal of Agricultural Research, 8(29), 3973-3975. http://dx.doi.org/10.5897/AJAR12.662

Nirmala, B., Vasudev, N., \& Suhasini, K. (2013). Farmer' s Perceptions on Hybrid Rice Technology: A Case Study of Jharkhand. Indian Research Journal of Extension Education, 13(3), 103-105. 
Parra-Lopez, C., De-Haro-Gimenez, T., \& Calatrava-Requena, J. (2007). Diffusion and Adoption of Organic Farming in the Southern Spanish Olive Groves. Journal of Sustainable Agriculture, 30(1), $105-151$. http://dx.doi.org/10.1300/J064v30n01_09

Poolsawas, S., \& Napasintuwong, O. (2013). Farmer Innovativeness and Hybrid Maize Diffusion in Thailand. Journal of International Agricultural and Extension Education, 20(2), 51-65.

Rashid, H. A., Julfiquar, A. W., \& Ali, S. (2011). History, Impact and Current Status of Hybrid Rice Research, Development and Delivery in Bangladesh. Dhaka, Bangladesh.

Rogers, E. M. (2003). Diffusion of Innovations. Book (5th ed., p. 512). Free Press.

Röling, N. (1988). Extension Science, Information Systems in Agricultural Development. Cambridge University Press.

Santiaguel, A. F., \& Quipot, L. M. (2012). Hybrids Head for the Tropics. Rice Today, 11(3), 40-41.

Sarker, M. A., Itohara, Y., \& Hoque, M. (2005). Determinants of adoption decisions: The case of organic farming ( OF ) in Bangladesh. Extension Farming Systems Journal, 5(2), 39-46.

Siraj, S. (2012). Hridoye Mati O Manush, Telecasted on 20 April, 2012, Channel I, Bangladesh.

Sofranko, A., Swanson, B., \& Samy, M. (2004). An Examination of the Extent of Innovation Discontinuance, the Motivations of Farmers Who Discontinue an Innovation, and Implications for Extension. In AIAEE 2004 proceedings of the 20th annul conference (pp. 694-705), Dublin, Ireland.

Spielman, D., Kolady, D., Ward, P., Rashid, H., \& Gulati, K. (2012). Public Expenditures, Private Incentives, and Technology Adoption: The Economics of Hybrid Rice in South Asia. IFPRI discussion paper 01233. Evireonment and Production Technology Division.

Tambo, J. A., \& Abdoulaye, T. (2011). Climate Change And Agricultural Technology Adoption: the Case of Drought Tolerant Maize in Rural Nigeria. Mitigation and Adaptation Strategies for Global Change, 17(3), 277-292. http://dx.doi.org/10.1007/s11027-011-9325-7

Udensi, U. E., Tarawali, G., Favour, E. U., Asumugha, G., Ezedinma, C., Okoye, B. C., Okarter, C., Ilona, P., Okechukwu, R., \& Dixon, A. (2011). Adoption of Selected Improved Cassava Varieties among Smallholder Farmers in South-Eastern Nigeria. Journal of Food, Agriculture \& Environment, 9(1), 329-335.

Yuan, L. (2012). Q \& A with the Father of Hybrid Rice. Rice Today, 11(3), 42-43.

\section{Copyrights}

Copyright for this article is retained by the author(s), with first publication rights granted to the journal.

This is an open-access article distributed under the terms and conditions of the Creative Commons Attribution license (http://creativecommons.org/licenses/by/3.0/). 